\title{
BMP-2 signaling in ovarian cancer and its association with poor prognosis
}

\author{
Cécile Le Page ${ }^{1}$, Marie-Line Puiffe ${ }^{1}$, Liliane Meunier ${ }^{1}$, Magdalena Zietarska1, \\ Manon de Ladurantaye ${ }^{1}$, Patricia N Tonin ${ }^{2,3}$, Diane Provencher ${ }^{1,4}$ and Anne- \\ Marie Mes-Masson*1,5
}

\begin{abstract}
Address: ${ }^{1}$ Centre de recherche du Centre Hospitalier de l'Université de Montréal (CR/CHUM)/Institut du cancer de Montréal, Montréal, Canada, ${ }^{2}$ Departments of Human Genetics and Medicine, McGill University, Canada, ${ }^{3}$ The Research Institute of the McGill University Health Centre, Montréal, Canada, ${ }^{4}$ Départment de gynécologie et obstétrique, Université de Montréal, Montreal, QC, Canada and ${ }^{5}$ Départment de Médicine, Université de Montréal, Montréal, Montréal, Canada

Email: Cécile Le Page - cecilelepage@yahoo.ca; Marie-Line Puiffe - marielinepuiffe@gmail.com; Liliane Meunier - liliane.meunier@gmail.com; Magdalena Zietarska - bmagda@yahoo.com; Manon de Ladurantaye - madel13@yahoo.com; Patricia N Tonin - patricia.tonin@mcgill.ca; Diane Provencher - diane.provencher@ssss.gouv.qc.ca; Anne-Marie Mes-Masson* - Anne-Marie.Mes-Masson@umontreal.ca

* Corresponding author
\end{abstract}

Published: 14 April 2009

Journal of Ovarian Research 2009, 2:4 doi:10.1186/1757-2215-2-4

This article is available from: http://www.ovarianresearch.com/content/2/I/4

(C) 2009 Le Page et al; licensee BioMed Central Ltd.

This is an Open Access article distributed under the terms of the Creative Commons Attribution License (http://creativecommons.org/licenses/by/2.0), which permits unrestricted use, distribution, and reproduction in any medium, provided the original work is properly cited.
Received: 15 December 2008

Accepted: 14 April 2009

\begin{abstract}
Background: We previously observed the over-expression of BMP-2 in primary cultures of epithelial ovarian cancer (EOC) cells as compared to normal epithelial cells based on Affymetrix microarray profiling [I]. Here we investigate the effect of BMP-2 on several parameters of ovarian cancer tumorigenesis using the TOV-2223, TOV-1946 and TOV-I I2D EOC cell lines.
\end{abstract}

Methods: We treated each EOC cell line with recombinant BMP-2 and assayed various parameters associated with tumorigenesis. More specifically, cell signaling events induced by BMP2 treatment were investigated by western-blot using anti-phosphospecific antibodies. Induction of IdI, Snail and Smad6 mRNA expression was investigated by real time RT-PCR. The ability of cells to migrate was tested using the scratch assay. Cell-cell adhesion was analyzed by the ability of cells to form spheroids. We also investigated BMP-2 expression in tissue samples from a series of EOC patients.

Results: Treatment of these cell lines with recombinant BMP-2 induced a rapid phosphorylation of SmadI/5/8 and Erk MAPKs. Increased expression of IdI, Smad6 and Snail mRNAs was also observed. Only in the TOV-2223 cell line were these signaling events accompanied by an alteration in cell proliferation. We also observed that BMP-2 efficiently increased the motility of all three cell lines. In contrast, BMP-2 treatment decreased the ability of TOV-1946 and TOV-I I 2D cell lines to form spheroids indicating an inhibition of cell-cell adhesion. The expression of BMP-2 in tumor tissues from patients was inversely correlated with survival.

Conclusion: These results suggest that EOC cell secretion of BMP- 2 in the tumor environment contributes to a modification of tumor cell behavior through a change in motility and adherence. We also show that BMP-2 expression in tumor tissues is associated with a poorer prognosis for ovarian cancer patients. 


\section{Background}

Epithelial ovarian cancer (EOC) is the second most common gynecological cancer and accounts for nearly half of all deaths associated with gynecological pelvic malignancies. Largely asymptomatic, over $70 \%$ of patients diagnosed with ovarian cancer at an advanced stage of the disease. Early detection is rare and screening programs in the general population have been unsuccessful. Recent studies have analyzed gene expression patterns to identify the molecular events involved in the development of cancer and to uncover diagnostic and prognostic markers. This approach, applied to ovarian cancer [2-10], has resulted in the identification of several hundred genes differentially expressed between NOSE (normal ovarian surface epithelia) and EOC [11]. In a previous study from our group [1] several candidate genes that discriminate NOSE from EOC cells were identified and validated by real time RT-PCR. The differential expression of one of these candidates, bone morphogenic protein-2 (BMP-2), was further validated by immunohistochemistry (IHC) of patient tissue samples [1].

The biological role of BMP-2 in ovarian cancer has not been elucidated. BMPs are members of the TGF- $\beta$ superfamily, which play an important role in embryonic development events, such as gastrulation, neurogenesis, hematopoiesis and apoptosis [12,13]. Recent studies have suggested that some BMPs are implicated in cancer development [14] as shown in breast and prostate cancer (reviewed in $[15,16]$ ). The effects of BMP-2 on cancer cells are controversial and are perhaps dependent on the tissue and environment where they are expressed [17]. For example, BMP-2 has been shown to stimulate the growth of pancreatic carcinoma cells and prostate cancer cells in absence of androgen [18,19]. On the other hand, BMP-2 clearly inhibits the growth of tumor cells of many origins including cancers arising from thyroid, androgen-dependent prostate in presence of androgen, myeloma, gastric and pancreatic cells [14,18-22]. In cancer cells, BMP-2 was found to suppress apoptosis induced by TNF $\alpha$ or by serum deprivation [23-25]. In ovarian cancer, overexpression of BMP-2, BMP-4 and BMP-7 mRNAs have been reported as dysregulated by microarray analyses $[1,7,8]$. A recent study has demonstrated the involvement of BMP-4 in the epithelial mesenchymal transition in human ovarian cancer cells [26]. Since BMP-2, along with family members BMP-4 and BMP-7, share the same receptors they may have similar effects. However, the binding affinity of BMPs on these receptors and subsequent receptor oligomerization are different which may lead to different downstream signaling and biological effects in response to BMPs $[15,27]$.

BMP-2 acts via two types of serine/threonine receptors [27]. Type I receptors are BMPR1a/Alk3 and BMPR1b/ Alk6 and type II receptors are BMPR2 and ActRIIA. Type I receptors are phosphorylated by type II receptors after oligomerization occurs. Of the two signaling pathways for $\mathrm{BMP}$, the Smad-dependent pathway appears to be the most important. Smad $1 / 5 / 8$ are mediators of BMPRIa and BMPRIb whereas Smad6 and Smad7 are the inhibitory Smads of this pathway [28] Phosphorylated Smad 1/ $5 / 8$ forms a complex with Smad4 and translocate in the nucleus (review [15]). The Smad-independent pathway activates TAK1, which can lead to MAPK activation as well as Akt and NF-kappaB activation [29,30]. The most characterized target genes of the BMP-2 signaling are Id 1 and Smad6 that encode products promoting the growth regulation of BMPs. The signaling pathway induced by BMP-2 can be modulated by numerous antagonist proteins, such as Noggin, Cerbarus and Gremlin. These antagonists are secreted in the extracellular matrix. Previous results using Noggin [26] and Chordin [31] support the potential therapeutic role of these antagonists in ovarian cancer progression through the inhibition of BMP signaling. It has also been reported that Gremlin gene expression is lower in ovarian cancer specimens compared to normal ovarian culture [28].

In the present study, we focused on the role of BMP-2 in ovarian cancer. First, we examined the biological role of BMP-2 on three novel ovarian cancer cell lines (TOV2223, TOV-1946, TOV-112D). These lines were selected since they do not express detectable levels of BMP-2, consequently, their sensitivity and response to recombinant BMP-2 protein was examined. The ability of BMP-2 to induce signaling pathways and expression of target genes was investigated. Functional assays were also performed to determine the in vitro behavior of these cell lines in response to BMP-2 treatment. Finally the association between BMP-2 and ovarian cancer patient survival was examined using ovarian cancer tissue array analysis.

\section{Methods}

\section{Cell culture and reagents}

The TOV-2223, TOV-1946 and TOV-112D cell lines, developed from long term passages of serous ovarian cancer samples as described previously [32,33], were grown at $37^{\circ} \mathrm{C}$ in $5 \% \mathrm{CO}_{2}$ and in OSE consisting of 50:50 medium 199:105 supplemented with 5\% fetal bovine serum (FBS) and $2 \mu \mathrm{g} / \mathrm{ml}$ Gentamicin. All reagents used for cell culture media were purchased from Wisent (Qc, Canada). Human recombinant BMP-2 (355-BM-010/CF) and mouse Noggin (\#1967-NG-025/CF) were supplied by R\&D system (Mineapolis, MN, USA). TNF- $\alpha$ was obtained from Roche Applied Science (Indianapolis, IN). BMP-2pCMV6-XL4 was purchased from Origene (Rockville, $\mathrm{MD}$ ) and cloned into pcDNA3.1 (Invitrogen Life Technologies, Carlsbad, CA) as a NotI fragment. The pcDNA3.1$\mathrm{BMP}-2$ gene was sequenced to confirm the correct insertion of BMP-2 cDNA in the pcDNA3.1 vector. 


\section{Primary cultures, tumor samples and patient characteristics}

Tumor samples were collected from surgeries performed at the Centre hospitalier de l'Université de Montréal (CHUM). An independent pathologist assigned histopathology and tumor grade according to International Federation of Gynecology and Obstetrics (FIGO) criteria. A gynecologic oncologist reviewed tumor stage and residual disease. Normal tissues were obtained from tumor-free participants that have undergone oophorectomy. Primary cell cultures from normal ovarian surface epithelia (NOSE) and EOC samples were established as described $[34,35]$. Cells in primary culture were maintained in OSE media supplemented with $10 \%(\mathrm{v} / \mathrm{v})$ fetal bovine serum (FBS), $2.5 \mathrm{ug} / \mathrm{mL}$ amphotericin B and $50 \mu \mathrm{g} / \mathrm{mL}$ gentamicin [34]. The tumor samples used for the tissue array studies are presented in Table 1. Tissue selection criteria for this study was based on all histopathologies from chemotherapy-naïve patients having provided informed consent with all samples having been collected between 1993-2003. Clinical data were extracted from the Système d'Archivage des Données en Oncologie (SARDO) that includes entries on tumor grade and stage, treatment and clinical outcomes such as the progression-free interval as defined by RECIST criteria and survival. No correlation between age of embedded paraffin tissues and antibody staining intensity on the tissue array was identified.

\section{ELISA}

Culture supernatants from confluent cellular monolayers were centrifuged at $3000 \mathrm{rpm}$ for $10 \mathrm{~min}$ and frozen at $80 \mathrm{C}$ until further use. All ascites fluids were re-centrifuged for $10 \mathrm{~min}$ at $8000 \mathrm{rpm}$ before performing ELISAs. After centrifugation, samples were tested by ELISA for secreted mature BMP-2 (item DBP200, R\&D System) concentration according to the manufacturer's instructions. The limit of detection for BMP-2 was $30 \mathrm{pg} / \mathrm{ml}$.

RNA preparation and Quantitative PCR

Total RNA from cell lines was prepared using the RNeasy kit from Qiagen (Qiagen Inc., ON, Canada). The cDNA synthesis was done according to the protocol of the SuperScript $^{\mathrm{TM}}$ First-Strand Synthesis System for real time PCR (Invitrogen Life Technologies, Carlsbad, CA) with a starting amount of $2 \mu \mathrm{g}$ RNA and reverse transcription performed with random hexamers. The PCR reaction was performed with a Rotor-gene 3000 Real-Time Centrifugal DNA Amplification System (Corbett tumor tissues Research, NSW, Australia). The Quantitect ${ }^{\mathrm{TM}}$ SYBR Green PCR (Qiagen) reaction mixture was used according to the manufacturer's instructions. Serial dilutions were performed to generate a standard curve for each gene tested in order to define the efficiency of the real time PCR reaction and a melt curve was done to confirm the specificity of the reaction. Based on the strong stability of ERK1 gene expression in ovarian cancer tissue, it was chosen as an internal control [1]. All experiments, including positive and negative controls, were performed in triplicate. The PCR primers targeted exonic sequences that were interrupted by at least one intron. The amplicons were sequenced to verify their specificity for the targeted genes. Primers were: Id 1 fw 5'-cggaatctgagggagaacaag, rev 5'-ctgagaagcaccaaacgtga; Smad6 fw 5'-gagctgagccgagagaaaga, rev 5'-agatgcacttggagcgagtt: Snail fw 5'-gagtggttcttctgcgctac, re v 5'-cagagtcccagatgagcatt; Wnt5a fw 5'-gcgcgaagacaggcatca aag, rev 3'-ggcgttcaccaccctgctg; Erk1 fw 5'-gcgctggctcacccctacct, rev 5'-gcccagggtgcagagatgtc, BMPR1a fw 5'-cttattcagctgcctgtggt, rev 5'-attcttccacgatcctcct; BMPR1b fw 5'tacaagcctgccataagtgaagaagc, rev 5'-tcatcgtgaaacaatatccgtctg and BMPR2: fw 5'-gctaaaatttggcagcaagc, rev 5'-cttgg gccct atgtgtcact.

\section{Western blot analysis}

Cells were lysed with cold lysis buffer (10 mM Tris- $\mathrm{HCl}$, $\mathrm{pH} 7.4,150 \mathrm{mM} \mathrm{NaCl}, 1 \mathrm{mM}$ EDTA, $1 \mathrm{mM}$ DTT/ $1 \mathrm{mM}$ $\mathrm{NaF} / 0.5 \% \quad \mathrm{NP}-40 / 0.5 \mathrm{mM} \quad \mathrm{PMSF} / 0.2 \mathrm{mM}$ sodium orthovanadate $/ 2 \mu \mathrm{g} / \mathrm{ml}$ of aprotinin, leupeptin and pepstatin), and the lysate boiled in loading buffer, separated by SDS-PAGE, and transferred onto a nitrocellulose membrane. Membranes were saturated with $5 \%(\mathrm{w} / \mathrm{v}) \mathrm{milk} /$ PBS/0.1\% Tween 20. Immunodetection was done as described in the ECL kit protocol (Amersham Pharmacia):

Table I: Composition of the ovarian cancer tissue array

\begin{tabular}{|c|c|c|c|c|c|c|c|}
\hline Histopathology & Number of samples & Low stage & High stage & Grade I & Grade 2 & Grade 3 & LMP \\
\hline Serous & 19 & 3 & 17 & 6 & 4 & 7 & 2 \\
\hline Endometrioid & 25 & 18 & 6 & 9 & 8 & 4 & 1 \\
\hline Clear cell & 15 & 10 & 5 & 2 & 2 & 8 & 3 \\
\hline Mucinous & 25 & 20 & 2 & 1 & 0 & 2 & 19 \\
\hline Mixed cells & 5 & 2 & 3 & 0 & 0 & 4 & 1 \\
\hline
\end{tabular}


i.e. incubated $2 \mathrm{~h}$ at room temperature with specific antibody, washed with PBS and incubated for another $30 \mathrm{~min}$ at room temperature with peroxidase-conjugated antibodies (Santa-Cruz Biotechnology Inc.). Western-blot analysis was performed with Erk1 (Santa Cruz Biotechnology Inc, CA), Smad1/5/8 (A-14 Santa Cruz Biotechnology Inc.), phospho-Erks (Cell Signaling, Beverly, MA, USA), phospho-Smad1/5/8 (Cell Signaling), p65 (Santa Cruz Biotechnology Inc), Akt (Santa-Cruz Biotechnology Inc.), phospho-Akt and phospho-S-536-p65 (Cell Signaling) and beta-Actin (AbCam, MA, USA) antibodies. All experiments were performed in triplicate with the TOV-2223 cell line and at least twice for the TOV-1946 and TOV$112 \mathrm{D}$ cell lines.

\section{Cytoplasmic and nuclear extracts}

To prepare cellular extracts, $5 \times 10^{6}$ cells were washed twice in cold PBS buffer and resuspended in lysis buffer containing $10 \mathrm{mM}$ Tris $\mathrm{pH} 7.9 / 10 \mathrm{mM} \mathrm{NaCl} / 5 \mathrm{mM}$ $\mathrm{MgCl}_{2} / 10 \mathrm{mM}$ sodium orthovanadate/0.5 mM PMSF/10 $\mu \mathrm{g} / \mathrm{ml}$ of the protease inhibitors (PMSF, pepstatin, leupeptin and aprotinin). After swelling the cells for $30 \mathrm{~min}$ on ice, $0.1 \%$ Nonidet P-40 and $10 \%$ glycerol $(\mathrm{v} / \mathrm{v})$ were added and the lysates centrifuged for $1 \mathrm{~min}$ at $4{ }^{\circ} \mathrm{C}$ and $5,000 \mathrm{rpm}$. Supernatants consisting of cytoplasmic extracts were carefully decanted for cytoplasmic extracts. Nuclei pellets were resuspended for $1 \mathrm{~h}$ in $40 \mu \mathrm{l}$ of lysis buffer containing $10 \mathrm{mM}$ Tris $\mathrm{pH} 7.9 / 400 \mathrm{mM} \mathrm{NaCl} / 0.1$ EDTA/0.5 mM DTT/5\% glycerol/0.5 mM PMSF/10 $\mu \mathrm{g} / \mathrm{ml}$ protease inhibitors. Particulate matter was eliminated by centrifugation for $10 \mathrm{~min}$ at $13,000 \times \mathrm{g}$ at $4{ }^{\circ} \mathrm{C}$. Protein concentrations were determined using the Bradford method.

\section{Transfection and luciferase reporter assay}

Cells were plated in 96-well plates and at 70-80\% confluence (approximately $5 \times 10^{4}$ cells), they were co-transfected with $0.2 \mu \mathrm{g}$ of DNA and $200 \mathrm{ng}$ of a constitutively active Renilla luciferase (pCMV-RL) (Promega, WI, USA) by the lipofectamine method (Invitrogen Life Technology). After $6 \mathrm{~h}$, cells were washed in fresh medium and incubated overnight. Cells were stimulated for $16 \mathrm{~h}$ with BMP-2 or TNF $\alpha$ and were then assayed for luciferase activity using the dual luciferase reporter assay system (Promega). The 3enh-kb-CONA-luc carries a firefly luciferase gene under the control of a trimeric repeat of the $\kappa B$ consensus [36].

\section{Cell proliferation}

To determine the effect of BMP-2 on cell growth, $5 \times 10^{4}$ cells were plated into six well culture plates. After allowing the cells to adhere overnight they were treated with recombinant BMP-2 and/or Noggin. Two, four and six days later, cells were detached with trypsin and counted in the presence of $0.05 \%$ Trypan blue using a hemacytometer. Untreated cells were used as controls.

\section{Migration assays}

Cells were grown to confluence in 6 well culture plates. Using a pipet tip, a wound was produced in the monolayer at two different positions on the plate. The adherent monolayer was then washed two times in PBS to remove non-adherent cells and media/FBS was added with or without BMP-2. After 20 or 40 hrs the open wound surface area was quantified by digital images taken under phase contrast microscopy. All experiments were repeated at least twice.

\section{Spheroid formation}

Spheroids were formed using a modification of the hanging droplet method [37]. Briefly, $4 \times 10^{3}$ cells were resuspended in $16 \mu \mathrm{l}$ of OSE/FBS media supplemented with 50 $\mathrm{ng} / \mathrm{ml} \mathrm{BMP-2}$ and placed on the cover of a $150 \mathrm{~mm}$ tissue culture plate. The cover was placed over a plate that contained $15 \mathrm{ml}$ of OSE to prevent dehydration of the hanging droplets. Spheroid formation was monitored after four and ten days, and representative spheroids were photographed. Untreated cells were used as controls.

\section{Tissue array and immunohistochemistry (IHC)}

A tissue array containing 94 cores of ovarian epithelial tissues was built (Table 1, [1]). A detailed protocol is described in Le Page et al, [1]. Briefly, the tissue array was heated at $60^{\circ} \mathrm{C}$ for $30 \mathrm{~min}$, de-paraffinized in toluene and rehydrated in a gradient of ethanol. Antigen retrieval was done in $90^{\circ} \mathrm{C}$ citrate buffer $(0.01 \mathrm{M}$ citric acid $+500 \mathrm{ul}$ Tween-20/L adjusted to pH 6.0) (J.T. Baker Philipsburg, NJ) for $15 \mathrm{~min}$. The tissue was blocked with a serum-free reagent (DakoCytomation Inc., Mississauga, ON) and incubated with BMP-2 antibodies (Santa-Cruz Biotechnology, CA, USA) overnight at $4^{\circ} \mathrm{C}$ in a humid chamber. Optimal antibody concentration was determined by serial dilutions. Endogenous peroxidase activity was quenched by treatment with $3 \% \mathrm{H}_{2} \mathrm{O}_{2}$. The array was incubated with a secondary biotinylated antibody (DakoCytomation Inc.) followed by incubation with a streptavidin-peroxidase complex (DakoCytomation Inc.) for $10 \mathrm{~min}$ at room temperature. Reaction products were developed using diaminobenzidine containing $0.3 \% \mathrm{H}_{2} \mathrm{O}_{2}$ as a substrate for peroxidase and nuclei were counterstained with diluted hematoxylin. Epithelial zones were scored according to the intensity of staining (value of 0 for absence, 1 for weak, 2 for moderate, 3 for high and 4 for very high intensity). Each array was independently analyzed in a blind study by two independent observers.

\section{Statistical analysis}

For survival and progression-free disease analyses, we used the Cox regression survival model with time dependent covariate and Kaplan-Meier curves coupled with the $\log$ rank test. Receiver operating characteristics (ROC) curves were generated for each marker to define a threshold of expression corresponding to the best sensitivity and 
specificity for patient survival. A threshold of BMP-2 intensity $=4$ appeared optimal. For Cox regression analysis, the markers were treated as categorical variables based on the threshold of expression. All statistical analyses were performed using SPSS software, version 11.0 (SPSS Inc., Chicago, IL, USA).

\section{Results}

Expression of BMP-2 in epithelial ovarian cancer cells

We have previously observed that BMP-2 expression is upregulated in primary cultures of epithelial ovarian cancer cells and epithelial ovarian cancer tissues as compared to normal surface epithelial cells (Figure 1A and [1]). In addition, supernatants of primary cultures of cancerous cells showed higher concentrations of BMP-2 than supernatants from NOSE cells (Figure $1 \mathrm{~B}$ ) demonstrating that an active mature form of BMP-2 is expressed by ovarian cancer cells and could be release in the microenvironment. To further investigate the expression of BMP-2, we also compared its mRNA expression in matched malignant ascites cells and solid tumor from the same patient. As shown in Figure 1C, more than half of the patients tested showed higher expression of BMP-2 in tumor cells from ascites compared to tumor cells from solid tumors. This difference was statistically significant $(\mathrm{p}=0.05, \mathrm{t}-$ test).

\section{BMP-2 activates SMAD I/5/8 and Erk MAPKs in ovarian cancer cell lines}

To investigate the role of BMP-2 in ovarian cancer cells we selected three cell lines, TOV-2223, TOV-1946 and TOV112D, for in vitro assays [33]. Microarray and RT-PCR analyses revealed that, although the three cell lines did not constitutively express BMP-2, they did express BMPR1a, BMPR1b and BMPR2 receptors (Table 2). Based on RNA expression, TOV1946 cells appear to express less BMPR2 receptor. In contrast the OV90 cell line [32] constitutively expressed BMP-2 but showed a very low expression of the corresponding receptors. These results suggested that the three cell lines, TOV-2223, TOV-1946 and TOV-112D could respond to endogenous stimulation with BMP-2.

To determine whether the BMP-2 signaling pathways were functional in these cell lines, we examined the effect of BMP-2 treatment on three main signaling pathways. We first stimulated cells with BMP-2 and examined the phosphorylation and nuclear translocation of Smad1/5/8, since BMP-2 is thought to predominantly act through the activation of these transcription factors. The ability of BMP-2 to phosphorylate Smad1/5/8 was examined by western-blot using an antibody, which specifically recog-

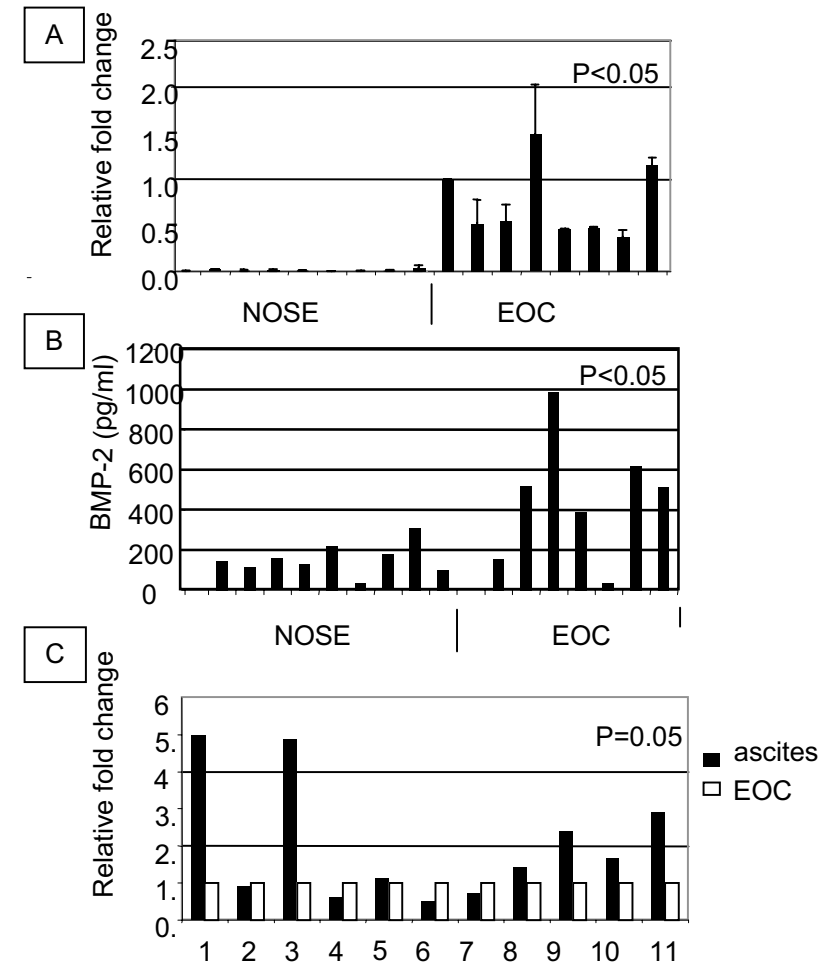

Figure I

A. BMP-2 expression in normal and malignant primary cultures. RNA expression levels were normalized to that of the control RNA by real time RT-PCR assays. Relative fold change expression was the ratio of the first EOC sample to that of other samples. Values represent the mean +/- SEM of two experiments. B. BMP-2 secretion in culture media of NOSE or EOC cell primary cultures. Cellfree supernatants were collected and tested for BMP-2 concentration by ELISA. Values represent the mean of duplicate experiments. Significance as compared to NOSE samples was defined as $p<0.05$ using a Student t-test. C. BMP-2 mRNA expression in primary cultures of EOC from solid tumor and ascites. Expression levels were quantified by real time RT-PCR and compared to the control RNA (Erk-I) Relative fold change expression was the ratio of the EOC from primary tumor sample to that of ascitic sample from the same patient. Values represent the mean of two experiments.

nizes the phosphorylated forms. As shown in Figure 2A, phosphorylation of Smad1/5/8 was induced after 20 minutes of treatment with as low as $10 \mathrm{ng} / \mathrm{ml} \mathrm{BMP-2} \mathrm{(Figure}$ 2A). As expected the nuclear translocation of $\mathrm{p}-\mathrm{Smad} 1 / 5 /$ 8 was concomitant to their phosphorylation within the cytoplasm (Figure 2B). This effect was inhibited in presence of Noggin. Based on findings with TOV2223, the 
Table 2: Gene expression of BMP receptors in ovarian cancer cell lines.

\begin{tabular}{llll}
\hline Gene/Cell line & TOV-II2D & TOV-1946 & TOV-2223 \\
\hline BMPRIa & 6.40 & 0.28 & 3.46 \\
\hline BMPR2 & 25.10 & 0.11 & 1.0 \\
\hline BMPRIb & 3.81 & 3.14 & 92.4 \\
\hline
\end{tabular}

RNA was extracted, retro-transcribed and used for real-time PCR using specific primers for BMPR Ia; BMPR Ib; BMPR2

response to BMP-2 in TOV-112D and TOV-1946 cell lines was tested with the maximal dose of $50 \mathrm{ng} / \mathrm{ml} \mathrm{BMP-2} \mathrm{(Fig-}$ ure 2).

BMP-2 has also been shown to induce mitogenic signaling through the activation of Erk MAPKs [38]. In our ovarian cancer cell lines, constitutive phosphorylation of Erk MAPKs was visible and a slight transient increase was induced in the cytoplasm after 20 min of BMP-2 treatment (Figure 2A). This effect was more evident in the nuclear compartment and was dose-dependent as well as inhibited by the presence of Noggin (Figure 2B). Similar findings were seen in TOV-112D and TOV-1946 cell lines treated with $50 \mathrm{ng} / \mathrm{ml} \mathrm{BMP-2} \mathrm{(Figure} \mathrm{2).}$

Altogether, these results show that BMP-2 can induce a classical SMAD signaling pathway and that BMP receptors are functional in the three cell lines used. Consequently, these cell lines appear to be a good model to study BMP2 effects on ovarian cancer cells.

\section{BMP-2 does not activate the Akt/NF-kB pathway}

BMP-2 was also suspected to induce NF-kappaB (NF-кB) activation through the TAK1 and Akt pathways [29]. To determine if BMP-2 stimulation leads to NF- $\kappa \mathrm{B}$ activation through the Akt pathway in ovarian cancer cell lines, we examined the phosphorylation of Akt and p65 using a specific antibody that recognizes phosphorylated serine sites. Neither constitutive nor BMP-2 induced phosphorylation of Akt was observed in TOV-2223 cells (Figure 2C) despite varying experimental conditions and film exposures. A weak and constitutive phosphorylation of Akt was seen in TOV-112D (not shown) and TOV-1946 (Figure 2C) cells but this basal level did not increase following BMP-2 treatment. Similarly, no constitutive or BMP-2 induced p 65 phosphorylation was observed in TOV-2223 (not shown). While a weak constitutive phosphorylation of p65 was observed in TOV-112D cells, no increased phosphorylation was detected after 20 min of BMP-2
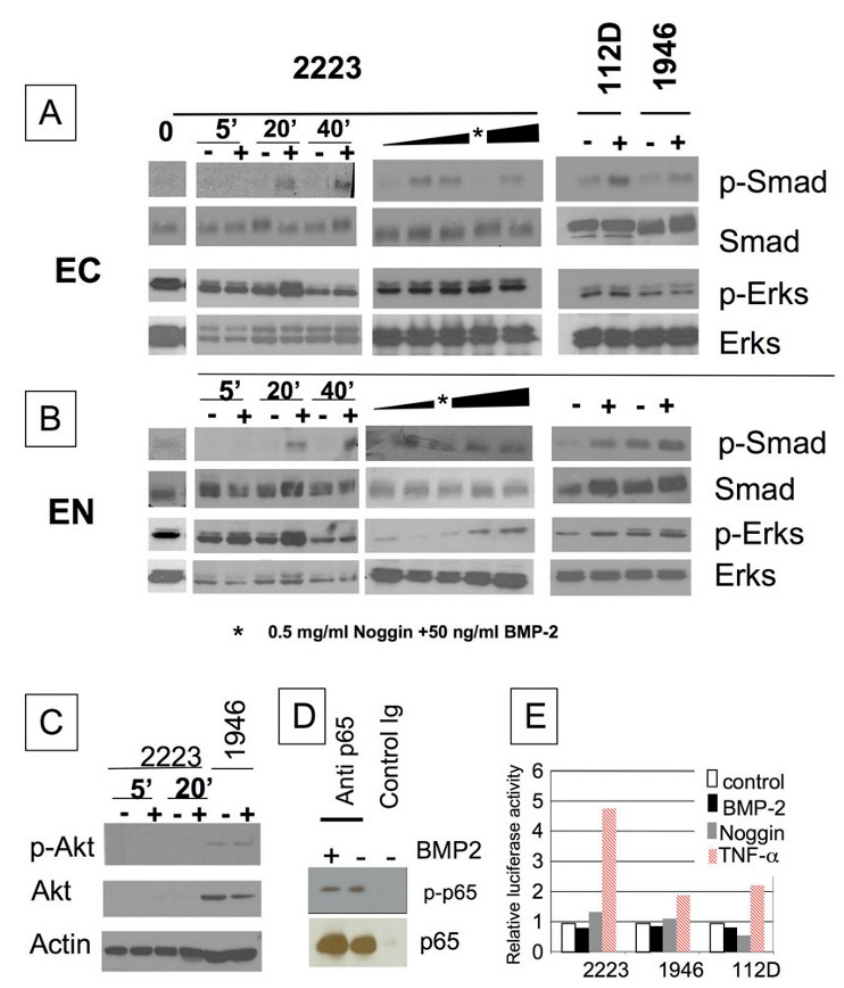

\section{Figure 2}

Modulation of Smad, ERK, Akt and NF- $\kappa$ B activation by BMP-2. A and B. TOV-2223 cells were stimulated in complete media for indicated times with $50 \mathrm{ng} / \mathrm{ml} \mathrm{BMP-2}$ (left) or for 20 min with increasing doses of BMP-2 (10, 50 or $100 \mathrm{ng} / \mathrm{ml}$ ). TOV-I I2D and TOV-I 946 cells were stimulated for $20 \mathrm{~min}$ with $50 \mathrm{ng} / \mathrm{ml}$ BMP-2. Cytoplasmic (EC) or nuclear (EN) extracts were subjected to western-blotting using anti-phosphoserine Smad I/5/8 and anti-phospho-tyrosine Erkl/2 antibodies. *Cells were stimulated with $50 \mathrm{ng} / \mathrm{ml}$ BMP-2 and $0.5 \mathrm{ng} / \mathrm{ml}$ Noggin C. Total extracts were subjected to western-blotting using anti-phosphoserine $473 \mathrm{Akt}$. TOV-2223 cells were stimulated for 5 or 20 min with $50 \mathrm{ng} /$ ml BMP-2. TOV-I 946 cells were stimulated with $50 \mathrm{ng} / \mathrm{ml}$ BMP-2 for 20 min. D. Total extracts from TOV-2223 cells were immunoprecipitated with anti-p65 antibody and loaded on an $8 \%$ polyacrylamide gel. Western-blotting was performed with anti-phosphoserine 536 p65. E. Cells were cotransfected with Renilla and $3 \kappa \mathrm{B}$-conA-luc vectors. Eight hours after transfection, cells were incubated with fresh media in the presence or absence of $50 \mathrm{ng} / \mathrm{ml} \mathrm{BMP-2}$ with or without $0.5 \mathrm{ng} / \mathrm{ml}$ Noggin or $10 \mathrm{ng} / \mathrm{ml}$ TNF $\alpha$ for $24 \mathrm{hrs}$. Cells were assayed for luciferase activity. Relative firefly luciferase activity was the ratio of luciferase activity in treated cells to that of non-treated cells. All experiments were repeated three times with similar results. 
treatment (Figure 2D). To further confirm the absence of NF- $\mathrm{BB}$ activation by BMP-2, we examined the transcriptional activity of NF- $\kappa B$ following BMP-2 treatment. TNF $\alpha$ stimulation was used as a positive control. The transcriptional activity of NF- $\mathrm{KB}$ was measured by transient transfection of a reporter plasmid carrying a $\kappa \mathrm{B}$ dependent promoter linked to a luciferase gene. After performing luciferase assays, no increases in $\kappa \mathrm{B}$ dependent luciferase activity was observed in any of the cell lines tested (Figure 2E).

\section{BMP-2 increases Id I, Smad6 and Snail expression in ovarian cancer cell lines}

We next examined whether the signaling pathways activated by BMP-2 led to the expression of known target genes of Smad such as ID1 and SMAD6. Since BMP-4 shares the same receptor with BMP-2, BMP4 may show effects similar to those seen with BMP-2, and therefore we also examined Snail expression, a BMP-4 regulated gene in ovarian cancer cells [26]. Real time RT-PCR analyses of each target gene showed that BMP-2 treatment increased Id1, Snail and Smad6 mRNA expression approximately two-fold (Figure 3). Time course experiments revealed that SNAIL expression was more transient than the induction of ID1 or SMAD6 expression.

A further increase in mRNA expression was not observed with doses higher than $10 \mathrm{ng} / \mathrm{ml}$ BMP-2. BMP-2 increased
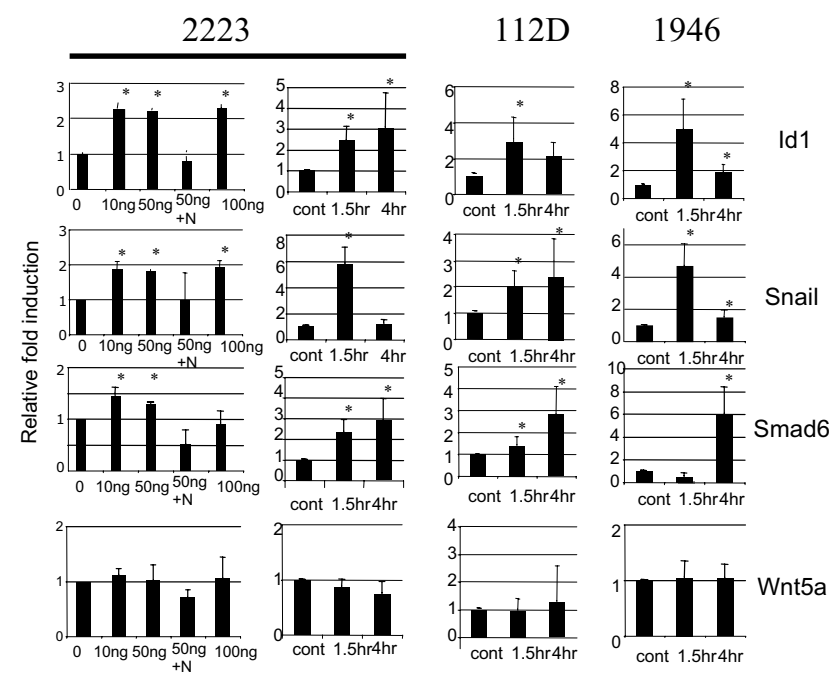

Figure 3

Gene expression induced by BMP-2. Cells were treated with $50 \mathrm{ng} / \mathrm{ml}$ BMP-2 in complete media or with indicated doses for $90 \mathrm{~min}$. Where indicated, $0.5 \mathrm{ng} / \mathrm{ml}$ Noggin (N) was used. RNA was extracted, retro-transcribed and used for real-time PCR using specific primers for Id I, Smad6, Snail or Wnt5a. Relative fold change expression was the ratio of treated cells to that of non-treated cells. Values are the mean +/- SEM of duplicate wells from at least two independent experiments. ${ }^{*} \mathrm{p}<0.05$ (Student t-test).
Id1, Snail and Smad6 expression in assays with TOV-223 and TO1946 cell lines but with slightly different kinetics than those seen with the TOV-2223 cell line. The largest fold change was observed in assays with TOV-1946 cells, which expressed the lowest constitutive level of Id1, Snail and Smail6 mRNA (data not shown). Wnt5a gene expression was used as negative control for gene expression assay as Wnt5a is not known to be regulated by BMPs. Indeed, q-RT-PCR showed that BMP-2 did not affect the expression of this gene confirming that the effect of BMP2 on Snail, Smad6 and Id1 expression is specific to BMP-2 stimulation.

BMP-2 affects the proliferation of ovarian cancer cell lines We examined whether BMP-2 affects cellular proliferation of ovarian cancer cells. As seen in Figure 4A, BMP-2 decreased the cellular proliferation rate of TOV-2223 cells in a dose dependent manner. This effect was inhibited by the presence of Noggin. However the growth of either TOV-112D or TOV-1946 cell lines was not significantly affected by doses of $50 \mathrm{ng} / \mathrm{ml}$ BMP-2 or higher (Figure $4 \mathrm{~A}$ ) (data not shown).

\section{BMP-2 increases cellular migration of ovarian cancer cell lines}

Cell migration in response to BMP-2 was estimated by the wound assays after 20 or 40 hours of treatment. The presence of BMP-2 in the culture media of TOV-2223 cells increased their motility in a dose dependent manner with a maximum effect being observed after 40 hrs of treatment with $100 \mathrm{ng} / \mathrm{ml}$ BMP-2 (Figure 4B). In TOV-112D and TOV-1946, a similar effect was observed after only 20 hrs of treatment with $50 \mathrm{ng} / \mathrm{ml}$ BMP-2 (Figure 4B).

\section{Effect of BMP-2 on spheroid formation}

We have previously demonstrated that the TOV-112D and TOV-1946 cells are able to grow as spheroids as opposed to TOV-2223 [33]. Since the relationship between these three-dimensional structures and migration remains poorly defined, we determined the effect of BMP-2 on the formation of in vitro spheroids. For this purpose the cell lines were incubated either in the absence or presence of $50 \mathrm{ng} / \mathrm{ml}$ BMP-2. The formation of spheroids was determined after four and ten days. As expected, the TOV-2223 cells were not able to form compact spheroid and the presence of BMP-2 did not affect the spheroid formation (Figure 4C). In contrast, we noted significantly more cell scattering in the TOV-112D and TOV-1946 spheroids after treatment with BMP-2 (Figure 4C).

\section{BMP-2 is associated with a poor prognosis in ovarian cancer patients}

We analyzed the association between patient outcome and BMP-2 protein expression by immunohistochemistry (IHC) using a tissue microarray of clinical samples from 89 ovarian cancer patients (Table 1 and Table 3 ) that was 


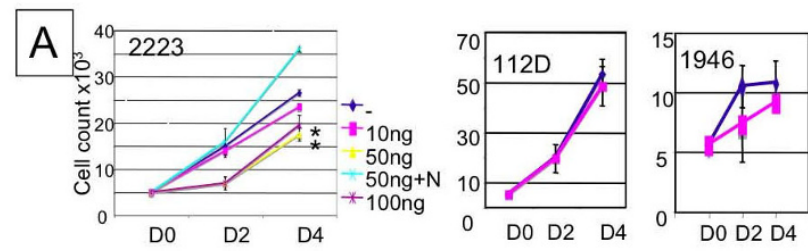

B
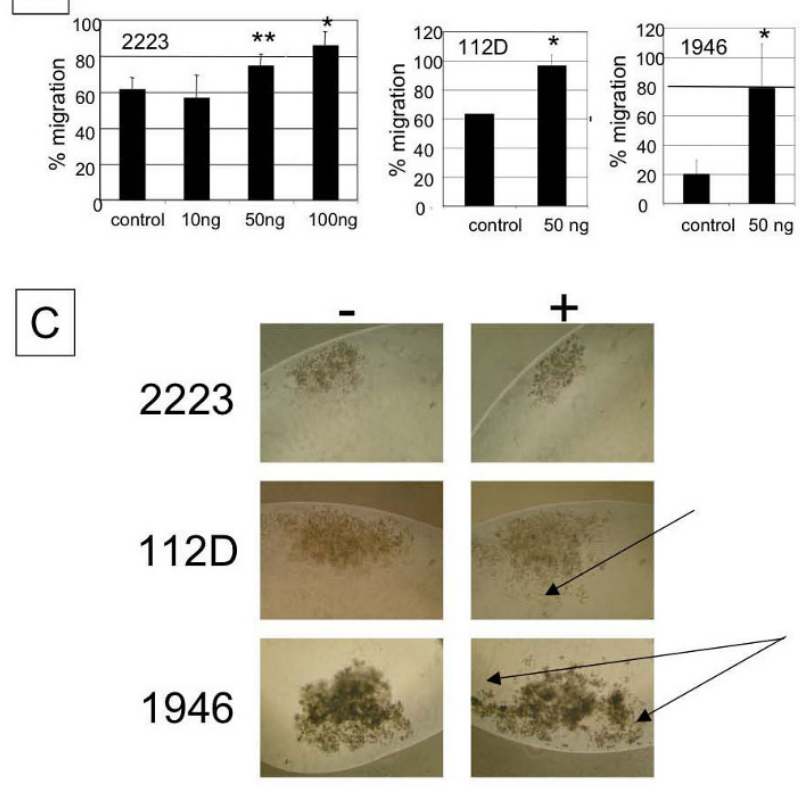

\section{Figure 4}

Effects of BMP-2 on proliferation, migration and spheroid formation. A. Cells were treated in complete media with indicated doses as indicated or with $50 \mathrm{ng} / \mathrm{ml}$ BMP-2 or left untreated for four days. Cells were counted every two days and media was changed every second day. Values are the mean +/- SEM of duplicate wells from at least two independent experiments. B. BMP-2 increases the motility of cells. Wounds were made on confluent monolayers of cells and then treated at indicated doses or with $50 \mathrm{ng} / \mathrm{ml}$ BMP-2. After $20 \mathrm{hrs}$ (TOV-2223) or $40 \mathrm{hrs}$ (TOV-I I2D and TOV-1946) the open wound surface area was quantified by digital images taken under a phase contrast microscope. Values are the mean +/- SEM of duplicates in at least two experiments and represent the percentage of total area covered by the cells in each image. C. Effect of BMP-2 on spheroid formation. Cells were cultured using a modification of the hanging droplet method. Cells were incubated in media with or without $50 \mathrm{ng} / \mathrm{ml}$ BMP-2. Spheroid formation was monitored after ten days. Arrows show scattered cells. All pictures were taken at a magnification of $100 \times$. For all figures $* p<$ $0.05, * * p<0.10$. (Student t-test). previously used to determine the potential of BMP-2 as a tumor marker [1]. Analysis of this tissue array showed that BMP-2 expression did not significantly correlate with age, stage or residual disease of patients. However, BMP-2 staining positively correlated with tumor grade $(\mathrm{r}=0.25$, $\mathrm{p}=0.02$, Spearman test). Kaplan Meier and Cox regression analyses also showed that BMP-2 expression was significantly associated with shorter survival period ( $\mathrm{p}=$ $0.029 \log$ rank) (Figure 5A) and with a high hazard ratio $(\mathrm{HR}=3.475,1.054-11.453)$. Since clinically low stage (III) disease has better outcomes that later stage (III-IV) disease, we also re-analyzed the data based on this stratification. Within low stage patients, BMP-2 was not associated with survival ( $\mathrm{p}=0.342, \log$ rank) in contrast to high stage patients where there was significant association ( $\mathrm{p}=$ 0.037, $\mathrm{HR}=5.851,1.112-30.787$ ) (Figure 5B).

\section{Discussion}

In this study we attempted to clarify the role of BMP-2 in ovarian cancer. An initial report highlighted the overexpression of BMP-2 in primary cultures of ovarian cancer cells and in the tissues of ovarian cancer patients [1]. Using three different cell lines, we report different in vitro and in vivo effects of BMP-2 on epithelial ovarian cancer cells. The three cell lines selected for this study expressed receptors for BMP-2 and were responsive to BMP-2 stimulation as seen by the activation and phosphorylation of Smad1/5/8 transcription factors as well as the gene expression of Id1, Snail and Smad6. However, although the signaling pattern was similar in all cell lines, they did not show the same biological activities in the presence of BMP-2. Only the TOV-2223 cell line showed a reduce proliferation rate in the presence of BMP-2 and was not influenced when cultured in 3D spheroid conditions. In contrast, the motility of all cell lines was stimulated in presence of BMP-2. Further work needs to be done to define particular characteristic of each ovarian cancer cell line that determine response to BMP-2. These results suggest that the effects of BMP-2 on ovarian cancer cells may be complex and dependent on the particular cellular context. The heterogeneity in response to BMP-2 is unlikely related to the histopathological subtype since TOV-2223 and TOV-1946, which respond differently to the presence of BMP-2, are both derived from a serous subtype.

Similar effects with BMP-4, as observed here with BMP-2, have recently been reported in ovarian cancer cell lines and ovarian cancer primary cultures $[26,39]$. We observed that BMP-2 slightly reduced the proliferation of TOV2223 cells but had no effect on TOV-112D and TOV-1946 


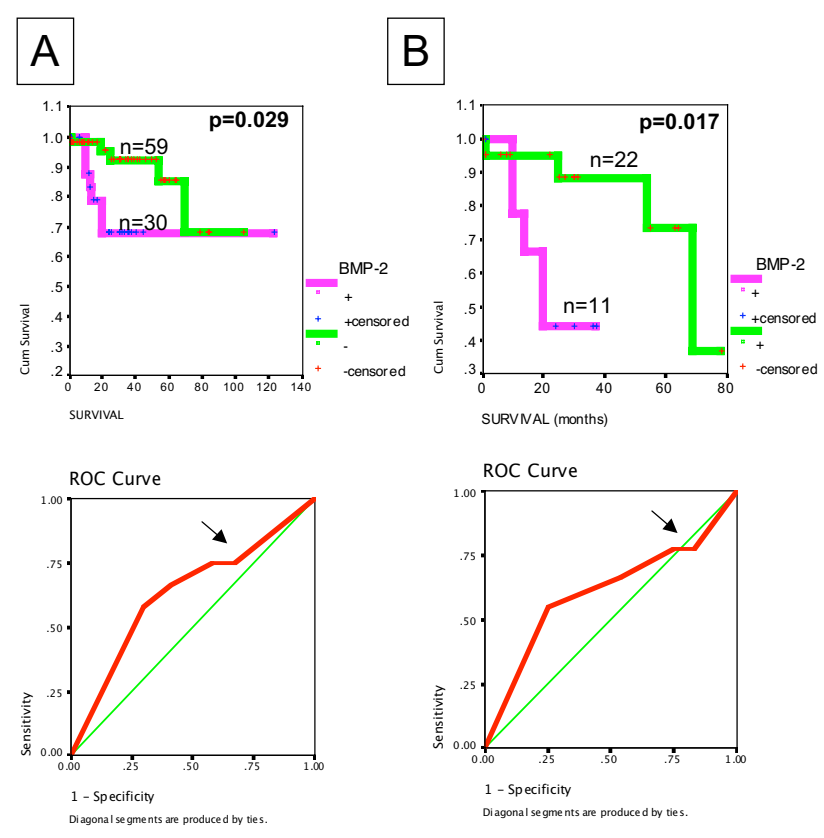

Figure 5

Association between BMP-2 and survival. Kaplan-Meier (top) and ROC (bottom) graphical representation of survival curves demonstrated a poorer survival associated with high expression of BMP-2 either in all tumors $(A)$ or high stage (III-IV) tumors (B). Log-rank test was used to verify the significance of the difference in survival $(p<0.05)$.

cells suggesting that some cell lines are resistant to the anti-proliferative activity of BMP-2. In the same way, BMP-4 has also been reported to slightly reduce the proliferation of SKOV3 ovarian cancer cells, as well as some primary cultures of ovarian cancer cells while other ovarian primary cultures were not sensitive to this protein [39]. The reason why some ovarian cancer cells are resistant to this anti-proliferative effect is unknown. We also observed similar increases in motility in cells treated with BMP-2 as reported by others with BMP-4 [26]. Since BMP-2 and $\mathrm{BMP}-4$ bind the same type I and type II BMP receptors, it is not surprising to notice similarities in their induction of signaling pathways. A strategy based on the single inhibition of either BMP-2 or BMP-4 may not be sufficient to reduce the tumorigenic effect driven by $S m a d 1 / 5 / 8$ signaling. In contrast, targeting several BMPs by the use of extracellular antagonists such as Chordin, Noggin or Gremlin may be more effective. Preliminary results shown here with Noggin and by others using Noggin [26] and Chordin [31] support the potential therapeutic role of these antagonists in ovarian cancer progression through the inhibition of BMP signaling. It will be of great interest to test Noggin, Chordin, Cerberus or Gremlin as in vivo potential tumor suppressors in xenograph models.
Table 3: Immunohistochemical staining of the ovarian cancer tissue array with an anti-BMP-2 antibody

\begin{tabular}{llllll}
\hline \multicolumn{1}{c}{ Staining: } & $\mathbf{O ( n )}$ & $\mathrm{I}(\mathrm{n})$ & $\mathbf{2 ( n )}$ & $\mathbf{3 ( n )}$ & $\mathbf{4 ( n )}$ \\
\cline { 1 - 5 } Histopatho: & & & & & \\
\hline Serous & 4 & 2 & 3 & 5 & 5 \\
\hline Endometrioid & 8 & 1 & 3 & 4 & 9 \\
\hline Clear cell & 0 & 0 & 1 & 0 & 14 \\
\hline Mucinous & 14 & 4 & 7 & 0 & 0 \\
\hline Mixed cells & 2 & 0 & 0 & 1 & 2 \\
\hline
\end{tabular}

$\mathrm{N}$ indicates the number of sample per staining intensity. Staining intensity is scored as 0: absent; I: weak; 2:moderate; 3:strong; 4: very strong. (See also reference I).

We also observed that some malignant cells from ascites samples overexpressed BMP-2 compared to cells from solid tumor samples of the same patients. The motility of cancer cells is an important factor determining the metastatic spread of tumors. As ascites tumor cells are detached from the primary tumor site and may have acquired a metastatic potential, this observation suggests that BMP-2 may be associated or involved in the process of evading tumor cells from the primary site to the omentum. In line with this hypothesis, we observed that BMP-2 stimulates the in vitro migration of ovarian cancer cell lines. In addition several reports have shown a role of BMP-2 in invasion of lung, prostate, breast cancer cells and BMP-4 in ovarian cancer $[21,40,41]$. To confirm the role of BMP-2 in the metastatic process of ovarian cancer cells, additional in vivo assays would be required. Metastasis is a major cause of cancer related mortality. The fact that patients with higher expression of BMP-2 in ovarian tissues have shorter survival supports a role for BMP-2 in the motility of ovarian cancer cells and aggressiveness of ovarian tumors. Further functional assays are required to determine the exact role of BMP-2 in these biological processes.

\section{Conclusion}

In conclusion, the evidence provided in this study support the fact that BMP-2 overexpression may modulate cellular motility and cellular adherence. In addition, we show that high expression of BMP-2 in ovarian cancer tissues is associated with shorter survival in patients.

\section{Competing interests}

The authors declare that they have no competing interests.

\section{Authors' contributions}

Conception, coordination and design of the study: CLP, $\mathrm{PT}$ and AMMM. Financial support to: PT, DMP and 
AMMM. Collection and analysis of clinical data: CLP, MdeL and DMP. Collection and analysis of molecular data: CLP, MP, MZ and LM. Collection and Assembly of data: CLP. Data analysis and interpretation: CLP, MdeL, $\mathrm{MZ}$ and LM. Manuscript writing: CLP and AMMM.

\section{Acknowledgements}

The authors are very grateful to the staff and patients at the Gynecologic Oncology Service at the Hôpital Notre-Dame for providing the samples. We thank Lise Portelance, Louise Champoux, Jean-Simon Diallo and Jason Madore for their assistance. MZ was supported by studentships from Canderel and Marc Bourgie funds of the Institut du cancer de Montréal, and Faculté des études supérieures de l'Université de Montréal.

This work was supported by a grant from the Canadian Institutes of Health Research (CIHR) to A.-M.M.-M., P.N.T. and D.M.P. Tumor banking was supported by the Banque de tissus et de données of the Réseau de recherche sur le cancer of the Fonds de la Recherche en Santé du Québec (FRSQ), affiliated with the Canadian Tumor Repository Network (CTRNet).

\section{References}

I. Le Page C, Ouellet V, Madore J, Ren F, Hudson TJ, Tonin PN, Provencher DM, Mes-Masson AM: Gene expression profiling of primary cultures of ovarian epithelial cells identifies novel molecular classifiers of ovarian cancer. $\mathrm{Br} J$ Cancer 2006, 94(3):436-445.

2. Adib TR, Henderson S, Perrett C, Hewitt D, Bourmpoulia D, Ledermann J, Boshoff C: Predicting biomarkers for ovarian cancer using gene-expression microarrays. $\mathrm{Br} J$ Cancer 2004, 90(3):686-692.

3. Lee BC, Cha K, Avraham S, Avraham HK: Microarray analysis of differentially expressed genes associated with human ovarian cancer. Int J Oncol 2004, 24(4):847-85I.

4. Lu KH, Patterson AP, Wang L, Marquez RT, Atkinson EN, Baggerly KA, Ramoth LR, Rosen DG, Liu J, Hellstrom I, Smith D, Hartmann L, Fishman D, Berchuck A, Schmandt R, Whitaker R, Gershenson DM, Mills GB, Bast RC Jr: Selection of potential markers for epithelial ovarian cancer with gene expression arrays and recursive descent partition analysis. Clin Cancer Res 2004, I 0( I 0):329|-3300.

5. Hibbs K, Skubitz KM, Pambuccian SE, Casey RC, Burleson KM, Oegema TR Jr, Thiele JJ, Grindle SM, Bliss RL, Skubitz AP: Differential gene expression in ovarian carcinoma: identification of potential biomarkers. Am J Pathol 2004, I 65(2):397-4I4.

6. Warrenfeltz S, Pavlik S, Datta S, Kraemer ET, Benigno B, McDonald JF: Gene expression profiling of epithelial ovarian tumours correlated with malignant potential. Mol Cancer 2004, 3:27.

7. Santin AD, Zhan F, Bellone S, Palmieri M, Cane S, Bignotti E, Anfossi S, Gokden M, Dunn D, Roman JJ, O'Brien TJ, Tian E, Cannon MJ, Shaughnessy J Jr, Pecorelli S: Gene expression profiles in primary ovarian serous papillary tumors and normal ovarian epithelium: identification of candidate molecular markers for ovarian cancer diagnosis and therapy. Int J Cancer 2004, I I 2(I): |4-25.

8. Donninger $\mathrm{H}$, Bonome $\mathrm{T}$, Radonovich M, Pise-Masison CA, Brady J, Shih JH, Barrett JC, Birrer MJ: Whole genome expression profiling of advance stage papillary serous ovarian cancer reveals activated pathways. Oncogene 2004, 23(49):8065-8077.

9. Lancaster JM, Dressman HK, Whitaker RS, Havrilesky L, Gray J, Marks JR, Nevins JR, Berchuck A: Gene expression patterns that characterize advanced stage serous ovarian cancers. J Soc Gynecol Investig 2004, I I(I):5I-59.

10. Le Page C, Ouellet V, Madore J, Hudson TJ, Tonin PN, Provencher DM, Mes-Masson AM: From gene profiling to diagnostic markers: IL-I 8 and FGF-2 complement CAI25 as serum-based markers in epithelial ovarian cancer. Int J Cancer 2006, I | 8(7): | 750- I 758.

II. Le Page C, Provencher D, Maugard CM, Ouellet V, Mes-Masson AM: Signature of a silent killer: expression profiling in epithelial ovarian cancer. Expert Rev Mol Diagn 2004, 4(2): I 57-I67.
12. Whitman M: Smads and early developmental signaling by the TGFbeta superfamily. Genes Dev 1998, I 2( I 6):2445-2462.

13. Botchkarev VA, Botchkareva NV, Sharov AA, Funa K, Huber O, Gilchrest BA: Modulation of BMP signaling by noggin is required for induction of the secondary (nontylotrich) hair follicles. J Invest Dermatol 2002, I I 8(I):3-10.

14. Hsu MY, Rovinsky S, Penmatcha S, Herlyn M, Muirhead D: Bone morphogenetic proteins in melanoma: angel or devil? Cancer Metastasis Rev 2005, 24(2):25 I-263.

15. Ye L, Lewis-Russell JM, Kyanaston HG, Jiang WG: Bone morphogenetic proteins and their receptor signaling in prostate cancer. Histol Histopathol 2007, 22( I 0): I I29- I I 47.

16. Chen D, Zhao M, Mundy GR: Bone morphogenetic proteins. Growth Factors 2004, 22(4):233-24I.

17. Suzawa M, Takeuchi Y, Fukumoto S, Kato S, Ueno N, Miyazono K, Matsumoto T, Fujita T: Extracellular matrix-associated bone morphogenetic proteins are essential for differentiation of murine osteoblastic cells in vitro. Endocrinology 1999, I 40(5):2 I 25-2 I 33.

18. Kleeff J, Maruyama H, Ishiwata T, Sawhney H, Friess H, Buchler MW, Korc $M$ : Bone morphogenetic protein 2 exerts diverse effects on cell growth in vitro and is expressed in human pancreatic cancer in vivo. Gastroenterology 1999, I I 6(5): I202-1216.

19. Ide H, Yoshida T, Matsumoto N, Aoki K, Osada Y, Sugimura T, Terada $M$ : Growth regulation of human prostate cancer cells by bone morphogenetic protein-2. Cancer Res 1997, 57(22):5022-5027.

20. Franzen A, Heldin NE: BMP-7-induced cell cycle arrest of anaplastic thyroid carcinoma cells via p2 I(CIPI) and p27(KIPI). Biochem Biophys Res Commun 200I, 285(3):773-78I.

21. Clement JH, Raida M, Sanger J, Bicknell R, Liu J, Naumann A, Geyer A, Waldau A, Hortschansky P, Schmidt A, Höffken K, Wölft S, Harris $A L$ : Bone morphogenetic protein 2 (BMP-2) induces in vitro invasion and in vivo hormone independent growth of breast carcinoma cells. Int J Oncol 2005, 27(2):40 I-407.

22. Wen XZ, Miyake S, Akiyama Y, Yuasa Y: BMP-2 modulates the proliferation and differentiation of normal and cancerous gastric cells. Biochem Biophys Res Commun 2004, 3 I 6(I): I 00-106.

23. Raida M, Clement JH, Ameri K, Han C, Leek RD, Harris AL: Expression of bone morphogenetic protein 2 in breast cancer cells inhibits hypoxic cell death. Int J Oncol 2005, 26(6): |465-|470.

24. Ro TB, Holt RU, Brenne AT, Hjorth-Hansen $H$, Waage A, Hjertner $O$, Sundan $A$, Borset M: Bone morphogenetic protein-5, -6 and -7 inhibit growth and induce apoptosis in human myeloma cells. Oncogene 2004, 23(I 7):3024-3032.

25. Chen S, Guttridge DC, Tang E, Shi S, Guan K, Wang CY: Suppression of tumor necrosis factor-mediated apoptosis by nuclear factor kappaB-independent bone morphogenetic protein/ Smad signaling. J Biol Chem 200I, 276(42):39259-39263.

26. Theriault BL, Shepherd TG, Mujoomdar ML, Nachtigal MW: BMP4 induces EMT and Rho GTPase activation in human ovarian cancer cells. Carcinogenesis 2007, 28(6): I I53-I I 62.

27. Nohe A, Keating E, Knaus P, Petersen NO: Signal transduction of bone morphogenetic protein receptors. Cell Signal 2004, I 6(3):291-299.

28. Quinn MC, Provencher DM, Mes-Masson A-M, Tonin PN: Reprogramming of the transcriptome in a novel chromosome 3 transfer tumor suppressor ovarian cancer cell line model affected molecular networks that are characteristic of ovarian cancer. Mol Carcinog 2008 in press.

29. Sugimori K, Matsui K, Motomura H, Tokoro T, Wang J, Higa S, Kimura T, Kitajima I: BMP-2 prevents apoptosis of the N I5 I I chondrocytic cell line through PI3K/Akt-mediated NF-kappaB activation. J Bone Miner Metab 2005, 23(6):4 I I-4I9.

30. Lee SW, Han SI, Kim HH, Lee ZH: TAKI-dependent activation of AP-I and c-Jun $\mathrm{N}$-terminal kinase by receptor activator of NF-kappaB. J Biochem Mol Biol 2002, 35(4):37l-376.

31. Moll F, Millet C, Noel D, Orsetti B, Bardin A, Katsaros D, Jorgensen C, Garcia M, Theillet C, Pujol P, François V: Chordin is underexpressed in ovarian tumors and reduces tumor cell motility. FASEB J 2006, 20(2):240-250.

32. Provencher DM, Lounis H, Champoux L, Tetrault M, Manderson EN, Wang JC, Eydoux P, Savoie R, Tonin PN, Mes-Masson AM: Characterization of four novel epithelial ovarian cancer cell lines. In Vitro Cell Dev Biol Anim 2000, 36(6):357-36I. 
33. Ouellet $\mathrm{V}$, Zietarska M, Portelance L, Lafontaine J, Madore J, Puiffe ML, Arcand SL, Shen Z, Hebert J, Tonin PN, Provencher DM, MesMasson AM: Characterization of three new serous epithelial ovarian cancer cell lines. BMC Cancer 2008, 8(I): 152 .

34. Kruk PA, Maines-Bandiera SL, Auersperg N: A simplified method to culture human ovarian surface epithelium. Lab Invest 1990, 63(I): $132-136$.

35. Lounis H, Provencher D, Godbout C, Fink D, Milot MJ, Mes-Masson AM: Primary cultures of normal and tumoral human ovarian epithelium: a powerful tool for basic molecular studies. Exp Cell Res 1994, 2 1 5(2):303-309.

36. Le Page C, Sanceau J, Drapier JC, Wietzerbin J: Inhibitors of ADP. ribosylation impair inducible nitric oxide synthase gene transcription through inhibition of NF kappa B activation. Biochem Biophys Res Commun 1998, 243(2):45 I-457.

37. Zietarska M, Maugard CM, Filali-Mouhim A, Alam-Fahmy M, Tonin PN, Provencher DM, Mes-Masson AM: Molecular description of a 3D in vitro model for the study of epithelial ovarian cancer (EOC). Mol Carcinog 2007, 46(I 0):872-885.

38. Lou J, Tu Y, Li S, Manske PR: Involvement of ERK in BMP-2 induced osteoblastic differentiation of mesenchymal progenitor cell line C3HIOTI/2. Biochem Biophys Res Commun 2000, 268(3):757-762.

39. Shepherd TG, Nachtigal MW: Identification of a putative autocrine bone morphogenetic protein-signaling pathway in human ovarian surface epithelium and ovarian cancer cells. Endocrinology 2003, 144(8):3306-33।4.

40. Langenfeld EM, Calvano SE, Abou-Nukta F, Lowry SF, Amenta P, Langenfeld J: The mature bone morphogenetic protein-2 is aberrantly expressed in non-small cell lung carcinomas and stimulates tumor growth of A549 cells. Carcinogenesis 2003, 24(9): I445-I 454.

4I. Feeley BT, Gamradt SC, Hsu WK, Liu N, Krenek L, Robbins P, Huard J, Lieberman JR: Influence of BMPs on the formation of osteoblastic lesions in metastatic prostate cancer. J Bone Miner Res 2005, 20(I2):2189-2199.

Publish with Bio Med Central and every scientist can read your work free of charge

"BioMed Central will be the most significant development for disseminating the results of biomedical research in our lifetime. "

Sir Paul Nurse, Cancer Research UK

Your research papers will be:

- available free of charge to the entire biomedical community

- peer reviewed and published immediately upon acceptance

- cited in PubMed and archived on PubMed Central

- yours - you keep the copyright

Submit your manuscript here:

http://www.biomedcentral.com/info/publishing_adv.asp
BioMedcentral 